\title{
Induction Sintering of \%3 Cu Contented Iron Based Powder Metal Parts
}

\author{
Uğur ÇAVDAR \\ Department of Mechanical Engineering, Celal Bayar University \\ Muradiye Campus, PO Box: 45140 Manisa, TURKEY \\ Tel: 90-236-241-2144-45 (Inner :279) Fax: +90 $2362142143 \quad$ E-mail: ugur.cavdar@bayar.edu.tr
}

Enver ATİK

Department of Mechanical Engineering, Celal Bayar University

Muradiye Campus, PO Box: 45140 Manisa, TURKEY

Tel: 90-236-241-2144-45 (Inner :279)Ｆax: +90 $2362142143 \quad$ E-mail: enver.atik@bayar.edu.tr

\begin{abstract}
In this study; iron powder metals were sintered with induction heating process. Sintering process has been achieved with an induction generator that has $12 \mathrm{~kW}$ power supply and $30 \mathrm{kHz}$ frequency. ASC10029 grade iron powder was mixed with copper with a ratio of $\% 3$ and zinc stearat with a ratio of $\% 0.8$ of iron mass by weight. Several duration in the range of 1, 2 and 3 minutes was studied during induction sintering. Transverse rupture strength, hardness and microstructural investigations were done. Obtained mechanical properties and microstructures were compared with traditionally sintered samples. At the end of the induction sintering process for a period of 3 minutes, the maximum stress values that were obtained from traditionally oven-sintered samples for a period of 30 minutes are reached.
\end{abstract}

Keywords: Induction, Sintering, Iron based powder, Induction sintering, Copper Powder

\section{Introduction}

The sintering is a modification process which causes significantly an increase in resistance and recovery of the properties by supplying to interlink bits(German, R.M., 1984)(German, R.M., 2007).

The sintering process is generally performed in the sintering furnaces. The sintering furnace controls the heat and the time during the sintering loop. Additionally, it maintains the atmosphere and controls the heat treatment which provides the disposal of the lubricant and bindings. The sintering process is done in batch furnaces and continuous furnaces(German, R.M., 1984)(German, R.M., 2007).

The sintering process of an iron-based powder metal sample in a traditional furnace is performed at $1120^{\circ} \mathrm{C}$ in 30 minutes. The reason of performing the induction sintering is decreasing 30 minute-sintering duration to a shorter period.

Based on the literature sintering by induction was patented in 1988 in the USA under the name of "Induction sintering process and apparatus"(United States Patent, 1988). The most significant studies done on sintering by induction after that date have been done under the name of high frequency induction heat sintering which are called HFIHS. Parallel to our study, M. Nakamura et al. (Nakamura, M., 2003) took out the patent of rapid sintering of iron and steel by induction heat under hydrogen and nitrogen gases in 2003.

\subsection{HFIHS (High Frequency Induction Heat Sintering)}

HFIHS method is a method of rapid sintering like SPS (Spark Plasma Sintering) method. As compared to SPS, HFIHS is a new method of sintering (Kim, H.C., Kim, D.K., Woo, K.D., Ko, I.Y., Shon, I.J. 2007). This method is generally applied to ceramics, composites and bio materials. For example; are used in materials such as WC-Co (Kim, H.C., Oh, D.Y., Shon, I.J., 2004), uranium oxide (UO)(Yang, J.H., Kim, Y.W., Kim, J.H., Kim, D.J., Kang, K.W., Rhee, Y.W., Kim, K.S., Song, K.W., 2008), composite like WC-Ni, Fe, Co(Shon, I.J., Jeong, I.K., Ko, I.Y., Doh, J.M., Woo, K.D., 2007)(Kim, H.C., Shon, I. J., Munir, Z. A., 2006), WC- $\mathrm{Mo}_{2}$ C (Kim, H.C., Park, H.K., Jeong, I.K., Ko, I.Y., Shon, I.J., 2007), WC-TiC (Kim, H.C., Kim, D.K., Woo, K.D., Ko, I.Y., Shon I.J., 2007), WC-8\%Co(Kim, H.C., Jeong, I.K., Shon, I.J., Ko, I.Y., Doh, J.M., 2006), 8YSZ- $\mathrm{Fe}_{2} \mathrm{O}_{3}$ (Shon, I.J., Jeong, I. K., Park, J.H., Kim, B.R., Lee, K.T., 2007), $\mathrm{TiB}_{2}-\mathrm{WB}_{2}$ (Shibuya, M., Ohanagi M., 2007), $\mathrm{NbSi}_{2}-\mathrm{Si}_{3} \mathrm{~N}_{4}$ (Park, H.K., Shon, I.J., Yoon, J.K., Doh, J.M., Ko, I.Y., 
Munir Z.A., 2008), bio ceramics like Hydroxyapatite (Hap) (Khalil, K.A., Kim, S.W., Darmaraj, N., Kim, K.W., Kim, H.Y., 2007) and $\mathrm{Al}_{2} \mathrm{O}_{3}-\left(\mathrm{ZrO}_{2}+3 \% \mathrm{Y}_{2} \mathrm{O}_{3}\right)$ (Khalil, K.A., Kim, S.W., 2007). When the powders which are generally placed between $\mathrm{Al}_{2} \mathrm{O}_{3}$ double axis blocks in the plate are pressed as double axis, they are sintered by high frequency induction coil.

Cavdar et al. studied iron and iron based powder metals for sintering samples with medium frequency induction sintering (Cavdar, U., Atik, E., 2008)( Cavdar, U., Atik, E., 2008)( Cavdar, U., Atik, E., 2008).

In our study, which differs from the previous studies, medium frequency was used. Moreover, the sintering process was done after the powder metal pieces are pressed, not during the pressing process.

\section{Materials and Method}

The samples used in tests were produced by weight of ratio as $\% 3$ copper and iron powder. Zinc stearate as the ratio $\% 0.8$ by weight was used as the lubricant. Zinc stearate powder vanishes during the sintering process, zinc stearate functions only as a lubricant during the pressing.

The iron powder used in the tests was called ASC10029 which was produced by Hougenas (The characteristics are shown in Table 1). All of these three were mixed in 25 cycle / min. for 20 minutes to have a homogeneous mixture. The samples were sized 10x10x55 mm and they weighed 37 gr. The powder metal samples were produced by pressing in $600 \mathrm{MPa}$ pressure with one axis press.

A group of pressed metal powder samples were sintered in a traditional sintering furnace, some parts of these were sintered in argon gas environment, another part in atmosphere environment. The other group was sintered by a $2 \mathrm{~kW} 30$ $\mathrm{kHz}$ induction generator in the atmosphere environment. The sintering temperature was $1120^{\circ} \mathrm{C}$ during the traditional sintering process. The sintering process performed in conventional furnaces was finished in 30 minutes. Two different kinds of induction sintering processes were applied to the same sort of samples. The first sintering process lasted for 1, 2 and 3 minutes in induction sintering. Second sintering process was started with pre-sintering in a traditional sintering furnace at $500^{\circ} \mathrm{C}$ for 10 minutes and then samples were sintered at 1,2 and 3 minutes with an induction sintering generator. The heat of the sample was set as $1120^{\circ} \mathrm{C}$ by an infrared pyrometer during the induction sintering process.

The induction appliance and the sintering progress made by it which is shown in Figure 1.

Transverse rupture strength (TRS) tests were performed in Autograph Shimadzu AG-IS $100 \mathrm{kN}$, a universal test appliance used for comparing the sintered samples via traditional sintering process and sintered samples via induction sintering.

\section{Results and Discussion}

The results of transverse rupture strength experiments presented the average of at least 3 samples. The results are shown in Table 2. The break stretching of the samples sintered by induction for 3 minutes were nearly the same as of the samples sintered for 30 minutes by traditional sintering ovens.

The SEM pictures of the samples were taken from the broken surfaces which were formed as the result of transverse rupture strength tests. SEM pictures are only the pictures of the samples which were sintered in 1, 2 and 3 minutes by induction sintering.

In the SEM pictures, it is shown that the samples which were sintered for 3 minutes are sintered better than the ones that were sintered for 1 and 2 minutes. In the pictures of the broken surfaces of the samples, it is seen that the sintered powder forms neck shapes. These shapes are the proof of sintering. The breaking took place at these points.

\section{Conclusion}

Induction sintering is completed in a shorter period compared to conventional sintering. Maximum stress and break strain values accomplished in 3 minutes via induction sintering are accomplished in 30 minutes via conventional sintering.

Induction sintering is illustrated in SEM views. The best sintering process occurs in 3 minutes which is seen from broken surface views.

If pre-heating and atmosphere controls are made in sintering when high mechanic features can be obtained. In addition to this sample surfaces can have been high quality.

Energy consumption is lower in induction sintering.

Bobbin designing and using which is suitable to component shape and dimensions is important in induction sintering.

\section{Special Thanks}

To Prof. Dr. Cevdet Meriç (cmeric@fatih.edu.tr) and Prof. Dr. Haldun KARACA (haldun.karaca@deu.edu.tr) for their academic helps, to Toz Metal Inc. (http://www.tozmetal.com/english.htm), Aytaç Ataç (Aytac@tozmetal.com) for their help as the provider of the metal powders. 


\section{References}

Cavdar, U., Atik, E. (2008). "Induction sintering of \%3 cu contented iron based powder metal parts" 5th International Powder Metallurgy Conference Turkey, TOBB University, Ankara/Turkey, 8-12 October 2008.

Cavdar, U., Atik, E. (2008). "Iron based powder bushings sintering via induction generator" in Turkish, 5th International Powder Metallurgy Conference Turkey, TOBB University, Ankara/Turkey, 8-12 October 2008.

Cavdar, U., Atik, E. (2008). "Sintering with induction", International Powder metal Congress \& Exhibition, Rostengarten congress center, Euro PM2008, Mannheim/Germany, September 29th - 1st October, Vol.3, p.p: 33-38.

Cavdar, U., Atik, E. (2008). "The effects of powders size in Induction sintering”, in Turkish, 12. International Materials Symposium, October 15-17 2008, Pamukkale University Congress \& Cultural Center, Denizli, Turkey, vol.2 p.p: 1286-1290.

German, R.M. (1984). “Powder Metallurgy Science”, MPIF, USA, 1984, p.p: 7.

German, R.M. (2007). Translator editors: S. Sarıtaş, M. Türker, N. Durlu, “Toz Metalürjisi ve Parçalıklı Malzemeler İşlemleri” TTMD, Ankara, Türkiye, 2007.

http://www.hoganas.com/

Khalil, K.A., Kim, S.W., Darmaraj, N., Kim, K.W., Kim, H.Y. (2007). "Novel mechanism to improve toughness of the hyroxyapatite bio ceramics using high-frequency induction heat sintering", Elsevier, Journal of Materials Processing Technology 187-188 (2007) 417-420.

Khalil, K.A., Kim, S.W. (2006). "Mechanical wet-milling and subsequent consolidation of ultra-fine $\mathrm{Al}_{2} \mathrm{O}_{3}-\left(\mathrm{ZrO}_{2}+\mathrm{Y}_{2} \mathrm{O}_{3}\right)$ bio ceramics by using high-frequency induction heat sintering”, Science Press, Trans. Nonferrous Met. Soc. China 17(2007), accepted 13 September 2006, p.p:21-26.

Kim, H.C. , Kim, D.K. , Woo, K.D., Ko, I.Y., Shon I.J. (2007). “Consolidation of binderless WC-TiC by high frequency induction heating sintering", Elsevier, International Journal of Refractory Maters \& Hard Materials 26 (2008), Republic of Korea, accepted 18 January 2007, p.p: 48-54.

Kim, H.C., Jeong, I.K., Shon, I.J., Ko, I.Y., Doh, J.M. (2007). “ Fabrication of WC-8wt.\%Co hard materials by two rapid sintering processes” Elsevier, International Journal of Refractory Metals \& Hard Materials 25 (2007), Republic of Korea, accepted 4 September 2006, p.p: 336-340.

Kim, H.C., Kim, D.K., Woo, K.D., Ko, I.Y., Shon, I.J. (2007). "Consolidation of binderless WC-TiC by high frequency induction heating sintering”, Elsevier, International Journal of Refractory Maters \& Hard Materials 26 (2008), Republic of Korea, accepted 18 January 2007, p.p: 48-54.

Kim, H.C., Oh, D.Y., Shon, I.J. (2004). "Sintering of nanophase WC - 15 vol. \%Co hard metals by rapid sintering process", Elsevier, Refractory Metals \& Hard Materials 22(2004), South Korea, accepted 22 june 2004, p.p: $197-203$.

Kim, H.C., Park, H.K., Jeong, I.K., Ko, I.Y., Shon, I.J. (2008). "Sintering of binderless WC-Mo $\mathrm{C}_{2}$ hard materials by rapid sintering process", Elsevier, Ceramic International Vol. 34, Issue 6, August 2008, Republic of Korea, accepted 27 march 2007, p.p:1419-1423.

Kim, H.C., Shon, I. J., Munir, Z. A. (2006). "Rapid sintering of ultra - fine WC - 10 wt \% Co by high - frequency induction heating", Elsevier, International Journal of Refractory metals \& Hard Materials 24 (2006), accepted 5 July 2005, p.p: 427-431.

Nakamura, M. (2003). "Iron and steel - rapid sintering of steels by induction heating in hydrogen-nitrogen", I. Japan Soc., Patents, Metal-powder.net, March 2003, MPR, p. 33.

Park, H.K., Shon, I.J., Yoon, J.K., Doh, J.M., Ko, I.Y., Munir Z.A. (2007). “ Simultaneous synthesis and consolidation of nanostructured $\mathrm{NbSi}_{2}-\mathrm{Si}_{3} \mathrm{~N}_{4}$ composite from mechanically activated powders by high frequency induction-heated combustion" Elsevier, Journal of Alloys and Compounds 461 (2008), Available online 25 June 2007, p.p:560-564.

Shibuya, M., Ohanagi M. (2007). "Effect of nickel boride additive on simultaneous densification and phase decomposition of $\mathrm{TiB}_{2}-\mathrm{WB}_{2}$ solid solutions by pressure less sintering using induction heating", Elsevier, Journal of the European Ceramic Society 27 (2007), Japan, accepted 6 May 2006, p.p: 301-306.

Shon, I.J., Jeong, I. K., Park, J.H., Kim, B.R., Lee, K.T. (2007). “ Effect of $\mathrm{Fe}_{2} \mathrm{O}_{3}$ addition on consolidation and properties of $8 \mathrm{~mol} \%$ yttria- stabilized zirconia by high-frequency induction heated sintering (HFIHS)", Elsevier, Ceramics International Vol. 35, Issue 1, January 2009, accepted 6 November 2007, p.p: 363-368.

Shon, I.J., Jeong, I.K., Ko, I.Y., Doh, J.M., Woo, K.D. (2007). “ Sintering behavior and mechanical properties of WC-10Co, WC-10Ni and WC10Fe hard materials produced by high-frequency induction heated sintering" Elsevier, Ceramic International vol. 35, n:1, Republic of Korea, accepted 3 November 2007, p.p: 339-344. 
United States Patent, Patent Number: 4,720,615. Inventor: Jerry R. Dunn, Boaz, Ala; Assignee: Tocco, Inc., Boaz, Ala; Appl. No: 770,768; Date of patent: Jan.19.1988, USA.

Yang, J.H., Kim, Y.W., Kim, J.H., Kim, D.J. , Kang, K.W., Rhee, Y.W., Kim, K.S., Song, K.W. (2008). “ Pressure less rapid sintering of $\mathrm{UO}_{2}$ assisted by high frequency induction heating process“", The American Ceramic Society, 91 [10], 2008, p.p: 3202-3206.

\section{Tables and Figures:}

Table 1. The Characteristics of Metal Powder [3]

\begin{tabular}{|c|c|c|c|c|}
\hline & & \multicolumn{2}{|c|}{ SPECIFICATION } & \multirow[t]{2}{*}{ RESULT \% } \\
\hline & & Mín. & MAX. & \\
\hline \multicolumn{5}{|c|}{ GRANULOMETRY } \\
\hline B.S.S. MESH & MICRONS & & & \\
\hline 85 & 180 & & 0.0 & 0.0 \\
\hline 100 & 150 & & 0.5 & 0.3 \\
\hline 150 & 106 & & & 12.5 \\
\hline 200 & 74 & & & 19.1 \\
\hline 300 & 53 & & & 19.8 \\
\hline 350 & 45 & & & 11.6 \\
\hline-350 & 45 & 30.0 & 40.0 & 36.7 \\
\hline \multicolumn{5}{|c|}{ PHYSICAL PROPERTIES } \\
\hline Apparent Densty & $\mathrm{g} / \mathrm{cc}$ & 2.55 & 2.75 & 2.69 \\
\hline Flow & Secs & & 30 & 26 \\
\hline \multicolumn{5}{|c|}{ CHEMICAL ANALYSIS } \\
\hline Copper & $\%$ & 99.00 & & 99.74 \\
\hline Oxygen & $\%$ & & 0.15 & 0.08 \\
\hline
\end{tabular}


Table 2.3 point bending results

\begin{tabular}{|c|c|c|}
\hline & Max. Stress $\left(\mathbf{N} / \mathbf{m m}^{2}\right)$ & Break Strain (\%) \\
\hline \multicolumn{3}{|c|}{ By classical sintering in $1120^{\circ} \mathrm{C}, 30$ minutes sintered samples } \\
\hline Atmospheric environment & 285,6 & 2,8 \\
\hline Argon environment & 375,2 & 3,1 \\
\hline \multicolumn{3}{|c|}{ Induction Sintering, $1120^{\circ} \mathrm{C}$} \\
\hline $\begin{array}{l}1 \text { min. Sintering (Atmospheric } \\
\text { environment) }\end{array}$ & 93,6 & 1,2 \\
\hline $\begin{array}{l}2 \text { min. Sintering (Atmospheric } \\
\text { environment) }\end{array}$ & 236,6 & 3,3 \\
\hline $\begin{array}{l}3 \text { min. Sintering (Atmospheric } \\
\text { environment) }\end{array}$ & 318,2 & 3,1 \\
\hline \multicolumn{3}{|c|}{ Presintering $500^{\circ} \mathrm{C}, 10$ minutes + Induction Sintering, $1120^{\circ} \mathrm{C}$} \\
\hline $\begin{array}{l}1 \text { min. Sintering (Atmospheric } \\
\text { environment) }\end{array}$ & 310,6 & 2,6 \\
\hline $\begin{array}{l}2 \text { min. Sintering (Atmospheric } \\
\text { environment) }\end{array}$ & 335,2 & 4,6 \\
\hline $\begin{array}{l}3 \text { min. Sintering (Atmospheric } \\
\text { environment) }\end{array}$ & 348,3 & 4,1 \\
\hline
\end{tabular}

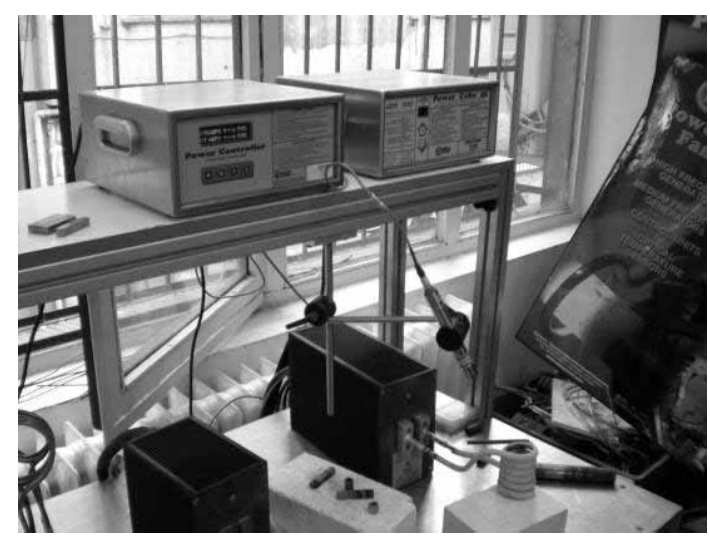

Figure 1. Induction Machine and Sintering Process (Celal Bayar University, research laboratory, Muradiye Campus Manisa, Turkey) 


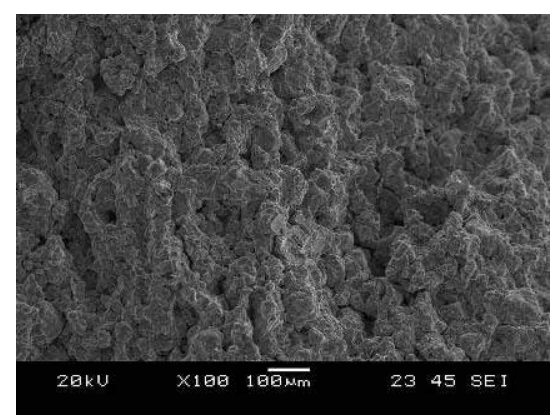

(a)

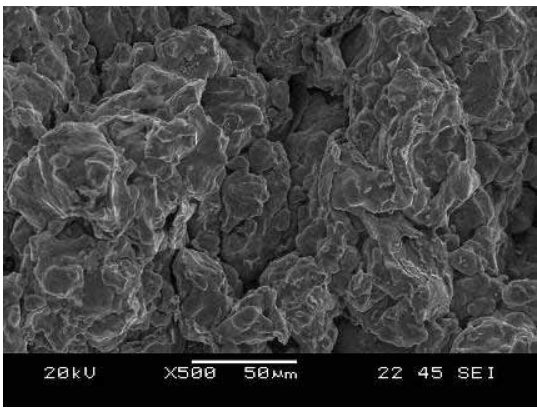

(c)

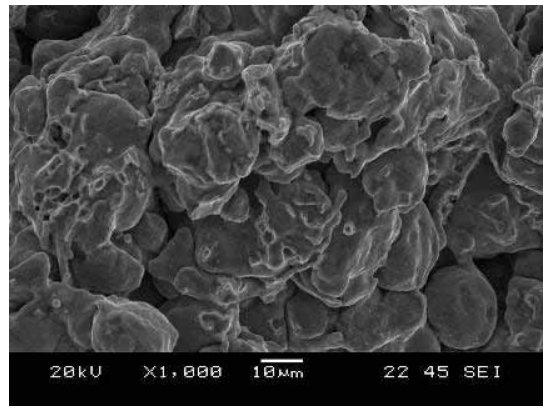

(e)

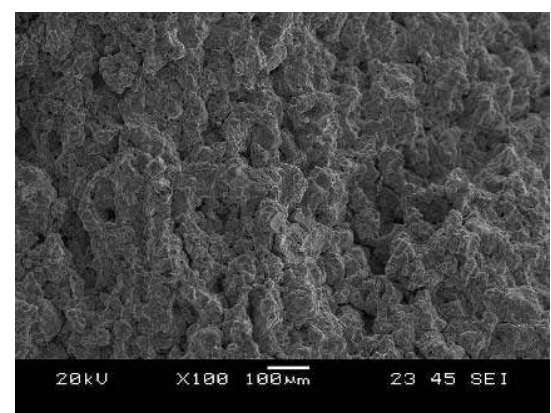

(b)

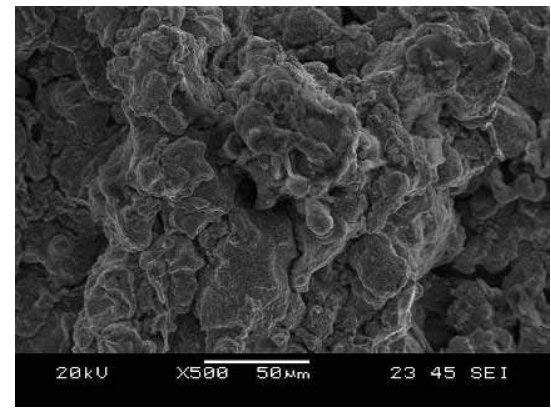

(d)

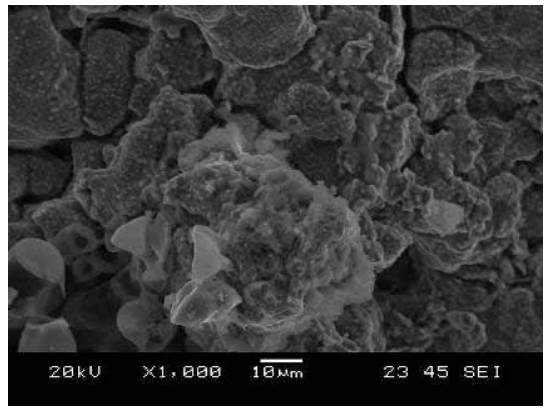

(f)

Figure 2. The structure of the samples of 1 minutes sintered by induction in $1120^{\circ} \mathrm{C}$.

a) 100x picture of inside part of broken surface, b) 100x picture of outside part of broken surface,

c) 500x picture of inside part of broken surface, d) 500x picture of outside part of broken surface,

e) 1000x picture of inside part of broken surface, and f) 1000x picture of outside part of broken surface are different places of SEM pictures of 1 minutes induction sintering sample.

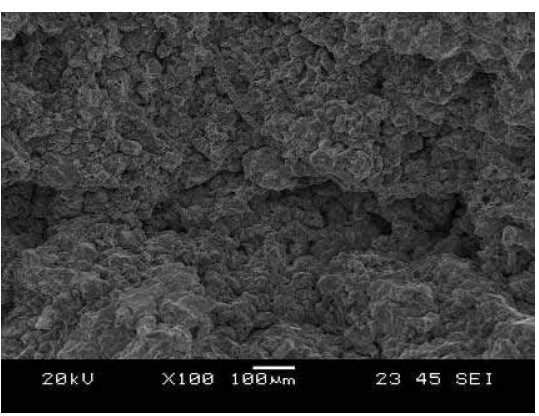

(a)

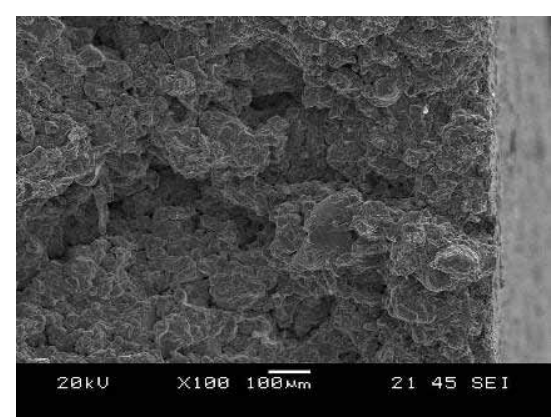

(b) 


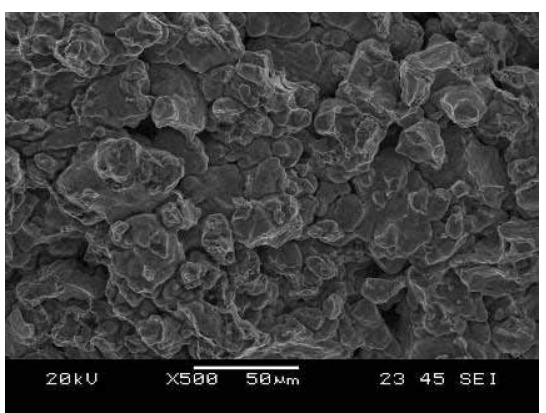

(c)

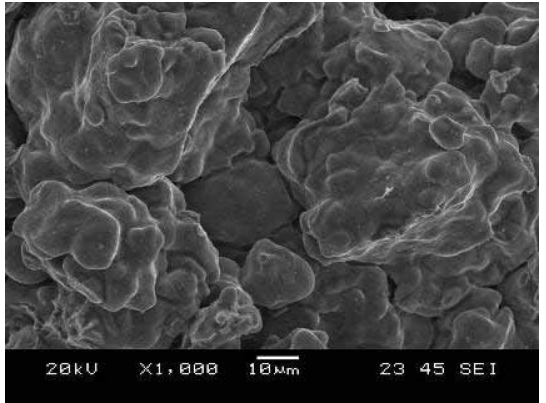

(e)

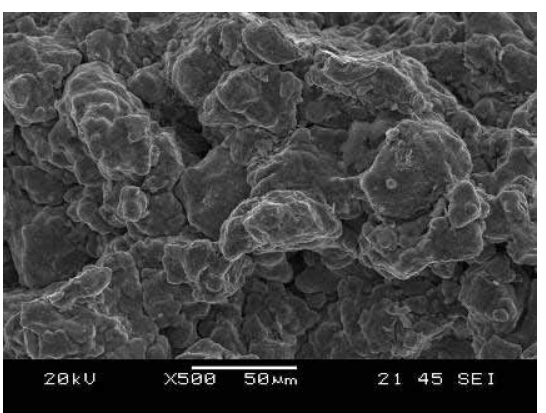

(d)

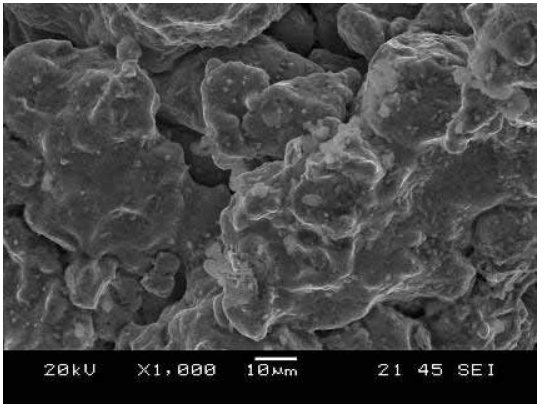

(f)

Figure 3. The structure of the samples of 2 minutes sintered by induction in $1120^{\circ} \mathrm{C}$ a) 100x picture of inside part of broken surface, b) 100x picture of outside part of broken surface, c) 500x picture of inside part of broken surface, d) 500x picture of outside part of broken surface, e) 1000x picture of inside part of broken surface, and f) 1000x picture of outside part of broken surface are different places of SEM pictures of 2 minutes induction sintering sample.

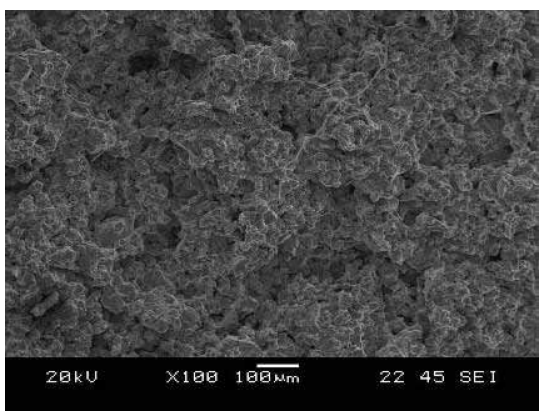

(a)

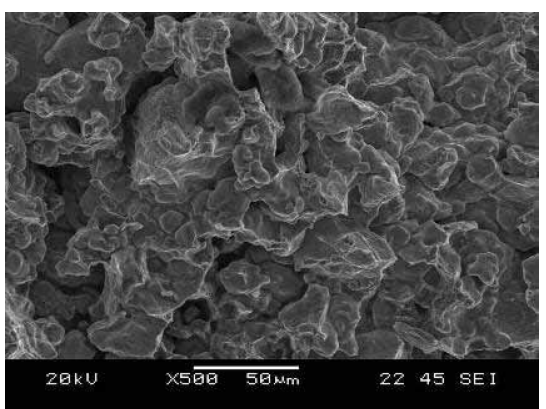

(c)

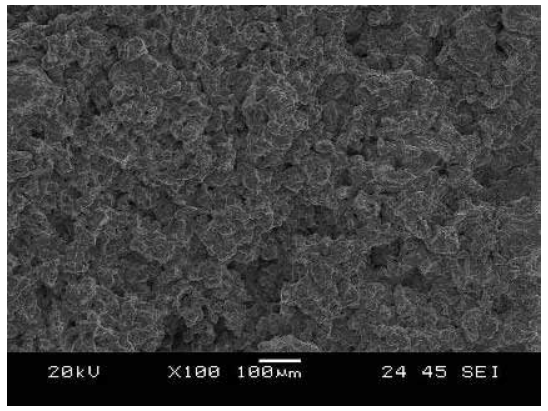

(b)

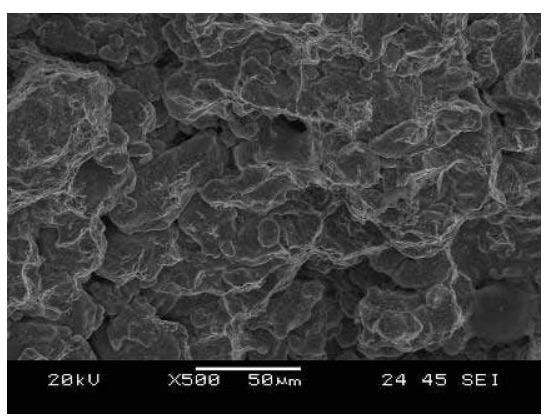

(d) 


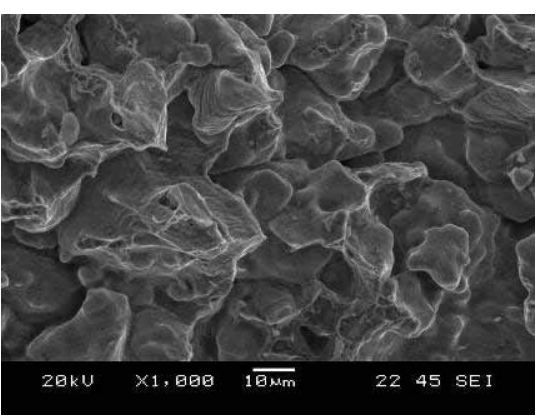

(e)

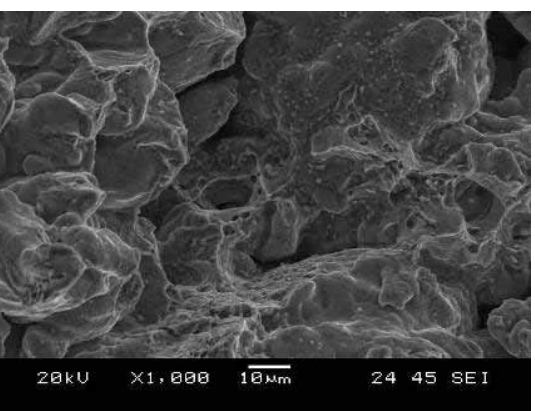

(f)

Figure 4. The structure of the samples of 3 minutes sintered by induction in $1120^{\circ} \mathrm{C}$

a) 100x picture of inside part of broken surface, b) 100x picture of outside part of broken surface,

c) 500x picture of inside part of broken surface, d) 500x picture of outside part of broken surface,

e) 1000x picture of inside part of broken surface, and f) 1000x picture of outside part of broken surface are different places of SEM pictures of 3 minutes induction sintering sample. 